\title{
Ethical values and leadership: a study of business school deans in Canada
}

\section{Nick Bontis* and Adwoa Mould-Mograbi}

\author{
DeGroote School of Business \\ McMaster University \\ 1280 Main Street West, DSB \#207 \\ Hamilton, Ontario L8S 4M4, Canada \\ E-mail: nbontis@mcmaster.ca \\ E-mail: amograbi@hotmail.com \\ *Corresponding author
}

\begin{abstract}
Ethical leadership in any organisation is expected to come from the top. With business leaders taking a real stand on ethics, it is imperative that business schools instil strong values into their students. Deans of business schools must exhibit these ethical values to provide an example for faculty, students and staff to emulate. This study is an investigation of the ethical values of deans and associate deans in ten business schools in Canada. The results portray the ethical inclination of business school leaders even with substantial monetary gains to be made. The moral climate as a result is discussed to provide further insight into the implications of the ethical values of these deans. Results indicate that although deans in Canadian business schools generally frown upon unethical behaviour, there are some fuzzy instances that still lead to questionable decisions and inconsistencies across the group.
\end{abstract}

Keywords: business ethics; values; business school deans; leadership.

Reference to this paper should be made as follows: Bontis, N. and Mould-Mograbi, A. (2006) 'Ethical values and leadership: a study of business school deans in Canada', Int. J. Business Governance and Ethics, Vol. 2, Nos. 3/4, pp.217-236.

Biographical notes: Dr. Nick Bontis is Associate Professor of Strategy at McMaster University. He received his doctoral education at the Ivey Business School, University of Western Ontario. His research expertise covers intellectual capital, knowledge management and organisational learning.

Adwoa Mould-Mograbi is a Research Associate at McMaster University. She graduated with a Bachelor of Commerce degree in 1999. Her work experience includes employment at a variety of organisations in the financial services industry.

\section{Introduction}

The issue of ethics is one that has received a lot of attention in recent years. It is a fundamental issue that is of concern to all business professionals as they face ethically ambiguous situations that require them to make sound decisions. For healthcare and medical professionals, among others, the issue of confidentiality ranks very high. 
For lawyers and engineers, there is the issue of being socially responsible and honest (Stiles, 1998). In business, major scandals involving governance activities such as insider trading, accounting irregularities, toxic waste, dumping and sexual harassment are only a few of the potential time bombs that exist.

Some high-profile corporations and individuals are now synonymous with unethical behaviour (e.g., Enron, WorldCom and Martha Stewart, to name a few). These celebrated cases created a media frenzy. In response, the US Congress approved the Sarbanes-Oxley Act by an overwhelming margin to reduce the conditions that lead to financial failure and to restore corporations to financial health and integrity through sound risk management and accounting practices.

However, the threat of corporate malfeasance continues to weigh on investors' trust of the marketplace. While businesses and their auditors proactively retool their focus on governance and transparency, the Association to Advance Collegiate Schools of Business International (AACSBI) board of directors established the Ethics Education Task Force in 2004 on the premise that the crisis in business ethics is not only a challenge for corporations but also an opportunity to strengthen management education. At issue is no less than the future of the free market system, which depends on honest and open enterprise to survive and flourish.

The main principle of business ethics is to provide guidance and assist an individual when making a complex and ethically ambiguous decision. Ethics is seen as character, responsibility, moral obligation and social justice. Ethics constitutes the set of values and beliefs that one holds (Manning, 1993). Even with the guidance of disciplines and professional organisations, making an ethical decision is still a complex process as it involves emotional and painful choices. The solution then, is to address these complex questions by developing policies that will require professionals to use knowledge, awareness and skill to make the right decisions (Stiles, 1998).

In businesses, corporations are responding positively to the growing interest in ethics and are concerning themselves with ethical issues that were ignored as recently as 20 years ago. There was a vague idea of what typified right and wrong conduct then, but corporations today are choosing to set up formal ethics departments to address the need (Cordtz, 1994). The increasing pressure from customers, government and employees is a key force motivating corporations and businesses to uphold ethical standards (MacMillan, 1995). According to a study conducted by the Centre for Business Ethics at Bentley College, approximately $90 \%$ of USA's largest corporations have a written code of ethics, one-third of them have a designated ethics officer, and one in five has an ethics department designed to monitor and uphold ethical standards (Cordtz, 1994). Corporate ethics programmes are set up to respond to the increasing pressures from customers, governments and competitors to educate employees about the values of their company, reduce the odds of ethical malpractice, and to establish systems that require compliance (Cordtz, 1994). Companies are discovering that responding positively to ethical issues is likely to improve their public image as well as profits. This fact is encouraging corporations to make outstanding efforts to follow ethical guidelines and their dedication to upholding standards are clearly portrayed through their mission statements (MacMillan, 1995; Bart et al., 2001).

The ethical climates of corporations are generally established by senior management and aim to shape the organisation's attitudes towards moral principles. Research has shown that corporate executives today hold very strong values and are eager to bring those values to the workplace (MacMillan, 1995). The guidelines that they set serve as a 
guide for all business employees and outline the authority, hierarchy and norms of appropriate behaviour expected of employees. These guidelines are depicted through the corporation's code of conduct, top management philosophy and the values held by the original founders or owners. It has been shown that formal codes are more effective than informal rules, however, on an informal level, to be effective, management must show a strong commitment to strong ethical standards to set the tone for it (Rozensher and Fergenson, 1994).

\section{Ethics in management education}

Few professions have been immune from public embarrassment and accusations, but some - such as MBA graduates - have become the target of highly visible publicity in the wake of corporate travesties. While there have been business scandals throughout the last century, the recent debacles have brought the focus to ethics and business schools. Some critics have charged business schools with teaching students to bend the rules to make the numbers. Others have maintained that business schools gloss over ethical conduct in examining business transactions and might go so far as to encourage students to bypass policies, procedures, and even the law, to ensure favourable financial results (AACSBI, 2004). The international accrediting body of business schools and their graduates goes on to say:

$$
\begin{aligned}
& \text { "To be sure, business schools cannot be expected to assume total responsibility } \\
& \text { for ethical debacles in corporations and throughout the business world. } \\
& \text { Education is hardly the sole determinant of human behaviour, and } \\
& \text { responsibility for ethics education is not the exclusive province of business } \\
& \text { schools. Nonetheless, ethics education has always been part of business } \\
& \text { curricula; and AACSBI accreditation standards have long mandated that ethics } \\
& \text { be taught as part of management degree curricula." (AACSBI, 2004, p.9) }
\end{aligned}
$$

The pressure on corporations to educate themselves regarding business ethics is a major factor in the increase in the number of schools offering ethics education. Even though not all schools have a designated course to teach business ethics, the issue is covered within the curriculum. From 1975 to 1980, there was a fivefold increase in ethics courses in US business schools. This increase is a response to the managerial need for ethically inclined employees (Cordtz, 1994). The increase in the number of business schools in North America teaching ethics is largely a result of the private sector and scandals of the late 1980s (MacMillan, 1995). As a result, the cynicism expressed by younger generations for corporate practices is greater than ever and makes them less pessimistic about the future (Webber, 1990).

The number of consultants, textbooks, case studies, seminars and conferences dedicated solely to the topic of business have increased dramatically in the past 20 years as well. To satisfy the need for knowledge, academic journals such as Business Ethics, Journal of Business Ethics, Business Ethics Quarterly, Business and Professional Ethics Journal, and Business and Society Review are a small sample of the amount of literature on the topic (Cordtz, 1994). The nature of internalisation of values makes it extremely difficult to find a common ground in the perceptions of individuals towards ethics. Even though it has been proven that ethical values and beliefs are instilled in people as they are raised, it is generally agreed that education in business education is the beginning of the attempt to instil ethics into society (Manning, 1993). 
As ethical standards are set through upper management, it is correctly assumed that business educators and deans are responsible for setting the ethical tone in their institutions. As leaders, one can only demonstrate strong ethical leadership by exhibiting ethical standards through their daily practices and leadership (Manning, 1993). In this case, the term 'leadership' refers to the universal functions of communication and knowledge management (Bontis, 1999). In order for academic leaders to demonstrate their commitment to strong values, they must have strong central values themselves and it is only through action that one can adequately demonstrate true dedication. As leaders of business schools, deans are expected to display strong ethical values in order to set the ethical tone of the institution. Outside of their normal concerns of sustaining enrolment, fund-raising, dynamic community relations and launching innovative programmes, deans must also deal with how well they are maintaining ethical standards (Halfond, 1990).

The increasing pressure of deans to respond to the growing strain of fund-raising in the USA is well documented by a study by Siguaw et al. (1998). Their objective was to investigate the ethical values of business academics in US-based AACSBI-accredited schools. The purpose of this present study is to extend that research and conduct a similar investigation into the ethical values of deans in Canadian business schools. The literature review will provide a historical background and fundamentals of the ethical theories and research conducted that explains the process of ethical decision-making. The methodology provides an overview of the instrument used for the purposes of this study while the sample characteristics provides an in-depth description of the respondents. The following sections outline an analysis based on the findings, discussion and conclusions.

\section{Literature review}

The literature on ethical theories is overwhelming. Instilling ethical values is a process that involves socialisation and internalisation of moral values. Generally speaking, ethics theory is based on two schools of thought: teleological ethics and deontological ethics.

Teleological ethics is established on the moral worth of actions and is determined solely by the consequences of one's actions (Beauchamp and Bowie, 1979). The most widely studied example of teleological theory is utilitarianism. Utilitarian ethics is based on the idea that one should "act so as to produce the greatest good for the greatest number" or so as to maximise the good for all. This consequentialist approach is concerned with the results of any actions and as long as the consequences are good, then the actions must be good (Poff and Waluchow, 1991). The maximisation of good is through efficiency, which in business means to maximise profits with the least amount of resources. The resulting production of goods is presumably intended to provide the greatest good for the greatest number (Beauchamp and Bowie, 1979).

On the other hand, deontological ethics is not based on one fundamental obligation but on the idea that one should "act so that you can consistently ensure that the principle of your action is universalised". This future-oriented approach is based on three formulations:

1 any action ought to be, in principle, applicable to all individuals in similar circumstances

2 one should treat individuals as ends not means 
3 the idea that one's actions must always serve to allow others to act rationally

(Poff and Waluchow, 1991).

A deontologist denies that the consequences of one's actions are what determine the rightness and wrongness of an action as the concept of duty is independent of the concept of good. The moral obligation is determined by a principle or general rule that defines how individuals perceive their actions and their reasons for performing them. The test of morality then is determined not by an assessment of consequences but by judging the coherence and consistency of the principle that one proposes to act on (Beauchamp and Bowie, 1979).

\section{Ethics education}

Businesses reward their employees based on the outcomes of their efforts; therefore, there is a primarily utilitarianism approach to doing business. Organisations may encourage unethical behaviours by promoting the final outcomes as more important than the means used to reach them (Siguaw et al., 1998). To understand how ethical theories are taught, one must understand the structure of ethics education and the role of deans as its leaders. The issue of ethics education is very controversial. One argument is that ethics cannot be taught in a classroom since ethical standards and moral values are developed as a result of upbringing.

Those who support the need for ethics education argue that formal education will enable students to learn how to deal with ethically ambiguous situations (Cordtz, 1994). There is no generally accepted theory of business ethics, however, it is treated as a study of moral reasoning. Scholars recognise the importance of business ethics as the foundation of sound, profitable and successful companies. Business educators, who include deans, professors, and chairpersons make a deep impact on future business leaders and can offer an insight into this growing phenomenon.

With regard to moral and ethical issues, business educators employ a wide variety of methods to facilitate ethical decision-making. These include monitoring through ethics committees, university-wide codes of ethics and dealing with problems as they arise (Fraedrich, 1990). In order to integrate ethics into the business curriculum, educators must develop procedures to increase the awareness of ethical dilemmas, develop a framework to shape how students will incorporate ethics into their decision-making, and develop methods for integrating ethics into the system through the actions of faculty members (Sherwin, 1992). Research has shown that business students have a strong desire to pursue financial success, therefore their ability to put profits as secondary in any ethical situation is less likely than other individuals (Halfond, 1990).

The values among students have changed dramatically from 30 years ago. Today, there is an increasing feeling of individualism, greater materialism and less reliance on religious beliefs and practices. Changing values are significant because they allow one to understand the motivations of individuals in the workplace and the values they attribute to certain aspects of their lives (French, 1997).

Business ethics have two elements, the theoretical principles and the application of these principles in the improvement of ethical reasoning. Business ethics base their moral decisions on the theories and principles of philosophers that deal directly with ethical behaviour and explore the basic principles that determine whether their behaviour is right or wrong (Glasbeek, 1990). For deans of business schools, several factors play a major 
role in determining how decisions are made. The structure of the organisation, the opportunity to engage in unethical decision-making, and the ethical standards of the institution are all variables that influence how deans make their decisions (Siguaw et al., 1998). The general sentiment that 'ethics is ethics' and 'business is business' assumes that even academic educators do not necessarily have to uphold moral principles and should conduct their daily practices as any businessman would and keep maximisation of profit as the highest priority (Beauchamp and Bowie, 1979). The ethical principles of deans are therefore more important than ever as they determine the ethical climate of their institutions and are responsible for instilling strong values among business students. The objective of this study is to analyse the perceptions of deans of Canadian business schools using various hypothetical dilemmas.

\section{Methodology}

A list of all of the business schools in Canada was generated using Canadian Business Magazine. Several schools on this list were removed because they:

- did not have an MBA programme

- did not use the GMAT exam for admission

- had not been in operation for at least ten years.

This left a sample size of 31 business schools that were targeted for data collection. A contact name and address for each dean was generated by searching each business school's website.

Questionnaires were then mailed with postage paid return envelopes, to the deans in the 31 Canadian business schools. They were asked to complete the surveys anonymously. Five completed responses were immediately returned, and with a reminder e-mail a couple of weeks later, an additional five were received, yielding a sample size of ten respondents and a response rate of $32 \%$. All respondents were married and had on average two children. Their ages ranged from 43 to 53 years with the mean age of 44 years. Of the ten responses, half were actually completed by deans while the other half were passed on for completion to the associate dean. On average, respondents had held their positions for three years. Respondents had previously worked in academia for an average of 15 years and all of them held doctorate degrees in various fields including finance, organisational behaviour, management information systems, strategic management, management sciences and accounting.

\section{Survey instrument}

The survey instrument was designed to measure and evaluate the ethical perceptions of deans by requiring them to respond to various situations. Their responses described how: (1) they felt about their personal actions, as well as (2) how they felt about other deans' actions. The surveys were targeted to show differences in the decision-making techniques used by deans when faced with ethically ambiguous situations and was modelled after a similar study by Siguaw et al. (1998) targeted to US business schools. 
The questionnaire consisted of five scenarios that presented the kinds of ethical dilemmas that deans are often faced with. Two versions of each scenario were presented with variations made in the variables, such as dollar amounts and the nature of the relationship of the subjects. This differs from the previous study in that two different versions of the surveys were not mailed out but both versions were mailed to the same dean. The complete scenarios are presented in the Appendix. Following each scenario, deans were asked to answer four items as follows:

- In my opinion, this action is ( $1=$ totally unethical, $7=$ totally ethical $)$

- In a similar situation, I would participate $(1=$ strongly disagree, $7=$ strongly agree $)$

- Business school deans generally participate in this type of activity $(1=$ strongly disagree, 7 = strongly agree)

- A dean who participates in this type of activity should be ( $1=$ forced to resign, 7 = rewarded).

The first two items were intended to measure their willingness (as well as their perceptions of their peers) to participate in unethical behaviour with different rewards reflected in the payoff matrix. The third element was used to measure their perception of level of ethics. The fourth element was to measure the perception of the level of punishment that a dean who was found acting on unethical grounds should receive. This last point would also allow analysis to be made on the correlation between what was perceived as unethical and the corresponding punishment attached to it.

\section{Results}

See Table 1 for a summary of all results. Scenario 1 is related to a 'Dean who clears a disciplinary action from an academic record'. An overwhelming majority $(80 \%)$ of respondents viewed the action of clearing a student's disciplinary record for a contribution of $\$ 1.5$ million as 'totally unethical', but only $70 \%$ thought it was 'totally unethical' if it were removed as a favour to a friend. Although $80 \%$ of respondents felt they themselves would never participate in such unethical activity, they felt that only $20 \%$ of others would never participate. This difference illustrates the perception of each respondent's own higher level of moral standards.

One respondent indicated that there might be a possibility he would clear a record for $\$ 1.5$ million but not for a friend. Finally, $40 \%$ of deans indicated that the dean in the scenario should be forced to resign if he accepted the contribution, while that number decreased to $30 \%$ in the case of the friendship. An interesting point here is that even though they felt that the decision was totally unethical, the level of punishment did not necessarily align with the act.

Scenario 2 is related to a 'Dean who admits an unqualified candidate'. This act is perceived to be 'totally unethical' by only half of the respondents when it is done for a close friend and even less (40\%) if it is for a major contributor. While none of the respondents indicated that the act was ethical, there were some respondents (20\%) who claimed it was only questionable if done for a major contributor. While half of the respondents said they would never participate in such an unethical act, one respondent said she would in the case of friendship and for a major contributor. In fact, while 
respondents were generally loathe to participate in this act for themselves, they perceived that $70 \%$ of other respondents were either indifferent to or would go ahead and admit the qualified candidate. While none of the respondents thought that the dean in the scenario should get rewarded for this action, only $20 \%$ thought she should actually be forced to resign if the favour were for a friend and $10 \%$ if the favour was for a major contributor. Overall, $20 \%$ indicated that there should be no punishment at all and this figure rose to $30 \%$ if it was to preserve a life-long friendship.

Table 1 Summary of all results for Scenarios A and B

\begin{tabular}{|c|c|c|c|c|c|c|c|}
\hline \multicolumn{8}{|c|}{ Scenario 1 - Dean clears disciplinary action from academic record } \\
\hline \multirow{3}{*}{ In my opinion, this action is $(\mathrm{A} / \mathrm{B})$} & \multicolumn{2}{|c|}{$\begin{array}{c}\text { Totally } \\
\text { unethical }\end{array}$} & \multicolumn{4}{|c|}{ Questionable } & \multirow{2}{*}{$\begin{array}{l}\text { Totally } \\
\text { ethical } \\
0 / 0\end{array}$} \\
\hline & $8 / 7$ & $1 / 1$ & $0 / 1$ & $1 / 1$ & $0 / 0$ & $0 / 0$ & \\
\hline & \multicolumn{2}{|c|}{$\begin{array}{l}\text { Strongly } \\
\text { disagree }\end{array}$} & \multicolumn{4}{|c|}{ Neither agree nor disagree } & $\begin{array}{l}\text { Strongly } \\
\text { agree }\end{array}$ \\
\hline $\begin{array}{l}\text { In a similar situation, I would } \\
\text { participate }(\mathrm{A} / \mathrm{B})\end{array}$ & $8 / 9$ & $0 / 1$ & $1 / 0$ & $1 / 0$ & $0 / 0$ & $0 / 0$ & $0 / 0$ \\
\hline \multirow{2}{*}{$\begin{array}{l}\text { Business School Deans generally } \\
\text { participate (A/B) }\end{array}$} & $2 / 2$ & $7 / 7$ & $0 / 1$ & $1 / 0$ & $0 / 0$ & $0 / 0$ & $0 / 0$ \\
\hline & \multicolumn{2}{|c|}{$\begin{array}{l}\text { Forced to } \\
\text { resign }\end{array}$} & \multicolumn{4}{|c|}{ No action taken } & Rewarded \\
\hline $\begin{array}{l}\text { A dean who participates in this type } \\
\text { of activity should be (A/B) }\end{array}$ & $4 / 3$ & $4 / 5$ & $1 / 1$ & $1 / 1$ & $0 / 0$ & $0 / 0$ & $0 / 0$ \\
\hline \multicolumn{8}{|c|}{ Scenario 2 - Dean admits unqualified applicant } \\
\hline & \multicolumn{2}{|c|}{$\begin{array}{c}\text { Totally } \\
\text { unethical }\end{array}$} & \multicolumn{4}{|c|}{ Questionable } & $\begin{array}{l}\text { Totally } \\
\text { ethical }\end{array}$ \\
\hline \multirow[t]{2}{*}{ In my opinion, this action is $(\mathrm{A} / \mathrm{B})$} & $5 / 4$ & $2 / 2$ & $1 / 2$ & $1 / 2$ & $0 / 0$ & $0 / 0$ & $0 / 0$ \\
\hline & \multicolumn{2}{|c|}{$\begin{array}{l}\text { Strongly } \\
\text { disagree }\end{array}$} & \multicolumn{4}{|c|}{ Neither agree nor disagree } & $\begin{array}{l}\text { Strongly } \\
\text { agree }\end{array}$ \\
\hline $\begin{array}{l}\text { In a similar situation, I would } \\
\text { participate }(\mathrm{A} / \mathrm{B})\end{array}$ & $5 / 5$ & $3 / 3$ & $1 / 1$ & $0 / 0$ & $0 / 0$ & $1 / 0$ & $0 / 1$ \\
\hline \multirow{2}{*}{$\begin{array}{l}\text { Business School Deans generally } \\
\text { participate (A/B) }\end{array}$} & $1 / 1$ & $2 / 3$ & $0 / 1$ & $5 / 2$ & $0 / 2$ & $2 / 0$ & $0 / 1$ \\
\hline & \multicolumn{2}{|c|}{$\begin{array}{l}\text { Forced to } \\
\text { resign }\end{array}$} & \multicolumn{4}{|c|}{ No action taken } & Rewarded \\
\hline $\begin{array}{l}\text { A dean who participates in this type } \\
\text { of activity should be }(A / B)\end{array}$ & $2 / 1$ & $3 / 4$ & $3 / 2$ & $2 / 3$ & $0 / 0$ & $0 / 0$ & $0 / 0$ \\
\hline \multicolumn{8}{|c|}{ Scenario 3 - Dean accepts backdated cheque } \\
\hline & \multicolumn{2}{|c|}{$\begin{array}{c}\text { Totally } \\
\text { unethical }\end{array}$} & \multicolumn{4}{|c|}{ Questionable } & $\begin{array}{l}\text { Totally } \\
\text { ethical }\end{array}$ \\
\hline In my opinion, this action is $(\mathrm{A} / \mathrm{B})$ & $2 / 2$ & $1 / 1$ & $0 / 1$ & $5 / 4$ & $2 / 0$ & $0 / 0$ & $0 / 0$ \\
\hline
\end{tabular}


Table 1 Summary of all results for Scenarios A and B (continued)

\begin{tabular}{|c|c|c|c|c|c|c|c|}
\hline \multirow[b]{2}{*}{$\begin{array}{l}\text { In a similar situation, I would } \\
\text { participate }(\mathrm{A} / \mathrm{B})\end{array}$} & \multicolumn{2}{|c|}{$\begin{array}{l}\text { Strongly } \\
\text { disagree }\end{array}$} & \multicolumn{4}{|c|}{ Neither agree nor disagree } & \multirow{2}{*}{$\begin{array}{c}\text { Strongly } \\
\text { agree } \\
1 / 1\end{array}$} \\
\hline & $2 / 2$ & $0 / 0$ & $1 / 1$ & $3 / 4$ & $2 / 1$ & $1 / 1$ & \\
\hline \multirow{2}{*}{$\begin{array}{l}\text { Business School Deans generally } \\
\text { participate (A/B) }\end{array}$} & $0 / 0$ & $3 / 2$ & $0 / 1$ & $4 / 4$ & $2 / 2$ & $1 / 1$ & $0 / 0$ \\
\hline & \multicolumn{2}{|c|}{$\begin{array}{l}\text { Forced to } \\
\text { resign }\end{array}$} & \multicolumn{4}{|c|}{ No action taken } & Rewarded \\
\hline $\begin{array}{l}\text { A dean who participates in this type } \\
\text { of activity should be (A/B) }\end{array}$ & $4 / 3$ & $0 / 1$ & $1 / 1$ & $5 / 5$ & $0 / 0$ & $0 / 0$ & $0 / 0$ \\
\hline \multicolumn{8}{|c|}{ Scenario 4-Dean keeps personal bequest } \\
\hline & \multicolumn{2}{|c|}{$\begin{array}{c}\text { Totally } \\
\text { unethical }\end{array}$} & \multicolumn{4}{|c|}{ Questionable } & $\begin{array}{l}\text { Totally } \\
\text { ethical }\end{array}$ \\
\hline \multirow[t]{2}{*}{ In my opinion, this action is $(\mathrm{A} / \mathrm{B})$} & $1 / 1$ & $3 / 3$ & $4 / 4$ & $0 / 0$ & $0 / 0$ & $0 / 0$ & $2 / 2$ \\
\hline & \multicolumn{2}{|c|}{$\begin{array}{l}\text { Strongly } \\
\text { disagree }\end{array}$} & \multicolumn{4}{|c|}{ Neither agree nor disagree } & $\begin{array}{l}\text { Strongly } \\
\text { agree }\end{array}$ \\
\hline $\begin{array}{l}\text { In a similar situation, I would } \\
\text { participate }(\mathrm{A} / \mathrm{B})\end{array}$ & $4 / 4$ & $2 / 2$ & $0 / 0$ & $4 / 3$ & $0 / 1$ & $0 / 0$ & $0 / 0$ \\
\hline \multirow{2}{*}{$\begin{array}{l}\text { Business School Deans generally } \\
\text { participate (A/B) }\end{array}$} & $4 / 3$ & $0 / 1$ & $1 / 1$ & $5 / 5$ & $0 / 0$ & $0 / 0$ & $0 / 0$ \\
\hline & \multicolumn{2}{|c|}{$\begin{array}{l}\text { Forced to } \\
\text { resign }\end{array}$} & \multicolumn{4}{|c|}{ No action taken } & Rewarded \\
\hline $\begin{array}{l}\text { A dean who participates in this type } \\
\text { of activity should be (A/B) }\end{array}$ & $2 / 2$ & $2 / 2$ & $1 / 1$ & $5 / 5$ & $0 / 0$ & $0 / 0$ & $0 / 0$ \\
\hline \multicolumn{8}{|c|}{ Scenario 5 - Dean distributes internal list } \\
\hline & \multicolumn{2}{|c|}{$\begin{array}{c}\text { Totally } \\
\text { unethical }\end{array}$} & \multicolumn{4}{|c|}{ Questionable } & $\begin{array}{l}\text { Totally } \\
\text { ethical }\end{array}$ \\
\hline \multirow[t]{2}{*}{ In my opinion, this action is $(\mathrm{A} / \mathrm{B})$} & $1 / 1$ & $2 / 2$ & $2 / 2$ & $0 / 0$ & $2 / 2$ & $1 / 1$ & $2 / 2$ \\
\hline & \multicolumn{2}{|c|}{$\begin{array}{l}\text { Strongly } \\
\text { disagree }\end{array}$} & \multicolumn{4}{|c|}{ Neither agree nor disagree } & $\begin{array}{l}\text { Strongly } \\
\text { agree }\end{array}$ \\
\hline $\begin{array}{l}\text { In a similar situation, I would } \\
\text { participate }(\mathrm{A} / \mathrm{B})\end{array}$ & $1 / 1$ & $3 / 3$ & $0 / 0$ & $2 / 2$ & $2 / 2$ & $0 / 0$ & $2 / 2$ \\
\hline \multirow{2}{*}{$\begin{array}{l}\text { Business School Deans generally } \\
\text { participate (A/B) }\end{array}$} & $1 / 1$ & $2 / 2$ & $1 / 1$ & $1 / 1$ & $2 / 2$ & $2 / 2$ & $1 / 1$ \\
\hline & \multicolumn{2}{|c|}{$\begin{array}{l}\text { Forced to } \\
\text { resign }\end{array}$} & \multicolumn{4}{|c|}{ No action taken } & Rewarded \\
\hline $\begin{array}{l}\text { A dean who participates in this type } \\
\text { of activity should be }(\mathrm{A} / \mathrm{B})\end{array}$ & $1 / 1$ & $2 / 2$ & $0 / 0$ & $7 / 7$ & $0 / 0$ & $0 / 0$ & $0 / 0$ \\
\hline
\end{tabular}


Scenario 3 is related to a 'Dean who accepts a backdated cheque from a contributor'. Half of the respondents were indifferent to the situation in the case for $\$ 10,000$. However, this dropped to $40 \%$ in the case of a $\$ 200,000$ cheque. Whereas, $40 \%$ of respondents claimed they would personally accept the cheque, only $30 \%$ felt that other deans would, regardless of the amount. Only $20 \%$ of the respondents said that this action was totally unethical regardless of amount. Finally, half of the respondents in this case felt that no action should be taken for accepting a backdated cheque regardless of the amount.

Scenario 4 is related to a 'Dean who personally keeps a willed bequest'. The results here were bipolar. Whereas, $80 \%$ of respondents thought the action was unethical for either sum of money, $20 \%$ of respondents said that the action was totally ethical in both cases. Whereas, $40 \%$ of respondents say they would personally not keep the bequest, $50 \%$ of respondents said that other deans would. Half of the deans in either case felt that no action should be taken towards a dean who kept the bequest for himself. Only two deans in either case felt the action was unethical enough to force a dean to resign.

Scenario 5 is related to a 'Dean who accepts a donation in exchange for information'. This scenario was split down the middle; half of the deans indicated that the action was ethical to some degree while the other half felt the action was unethical to some degree. Whereas, $40 \%$ of respondents agreed that they would participate in the exchange regardless of money, $40 \%$ disagreed that they ever would. Finally, $70 \%$ of respondents felt that no action should be taken against the dean who handed over a list of faculty and administrators' names.

\section{Discussion}

The aim of this study was to investigate the moral standards of deans in Canadian business schools and to provide some insight as to how deans make their decisions in indeterminate situations. As leaders of business schools, deans through their actions are more likely than any other member of the institution to have the greatest influence on the ethical tone of the organisation. There is increasing pressure on deans to raise funds for their institution, which makes them partial to situations where they may receive a substantial contribution in return for unethical favours.

Overall, the responses to the scenarios were positive in that the overwhelming majority of deans felt that all the actions were unethical to some degree. The previous study that was based in the USA found that deans relied on a teleological theory where the greatest good for the greatest number was the only obligation of individuals. In the US context, deans were found to be more partial to doing the action if the amount involved was significantly higher. Canadian deans however, relied on a strict deontological approach (Beauchamp and Bowie, 1979). They were more concerned with whether the action itself was ethical as opposed to concerning themselves with the monetary gain or the consequences involved. They followed the three formulations previously discussed by focusing on the general rules as opposed to the consequences involved. Regardless of the positive benefits offered, Canadian deans felt that unethical acts were wrong. This reasoning is expressed in the willingness not to participate in any of the scenarios they were presented with.

Even though removing a disciplinary action from a student's record was seen as completely unethical by an overwhelming majority, there was some doubt as to whether other deans were participating. This reasoning is consistent with the utilitarian approach 
where the action is intended to maximise the greatest good for the institution. In the case of accepting an unqualified applicant for a friend, only $20 \%$ thought the dean should resign if the favour was done for a friend and $10 \%$ if the favour was done for a major contributor. Clearly, there is a general feel that most of the respondents felt that no severe punishment should be enacted. There is still the sense that it is fine for the dean to still keep his position. In fact, one respondent indicated that the action was ethical if the favour was done for a major contributor.

Another interesting finding of the study was the fact that punishment did not adequately relate to the perceptions of totally unethical actions. In Scenario 1, $80 \%$ of deans indicated that the action was totally unethical, yet only $40 \%$ of them felt the dean should be forced to resign. In Scenario 2, 50\% of the respondents felt that the action was totally unethical, yet only $20 \%$ thought that she should be forced to resign. Scenario 3 had an interesting result because 50\% thought accepting a backdated cheque was a questionable action, yet $40 \%$ of them felt that the dean should be forced to resign. Keeping a bequest intended for the school is seen as unethical to some degree by $80 \%$ of respondents, yet $50 \%$ felt that no action should be taken. In the case of the dean having an exclusive agreement with a donor to pass on names of faculty and administrators, $60 \%$ felt that no action should be taken, even though $50 \%$ felt that the action was unethical to some degree.

The fact that deans do not feel that severe action should be taken could mean that even though they see the action as unethical, they feel there is no reason to be punished harshly for it. However, when there are harsh consequences for misbehaviour, there are more deterrents not to participate in such behaviour. Nevertheless, getting seriously reprimanded for infractions is not enough to discourage unethical behaviour. Individuals need to feel a strong sense of morality and losing one's job over infringement of codes could be a bigger disincentive than any sort of punishment. One reason that deans may have answered 'totally unethical' to these situations may have been because business ethics seem to be an important issue currently pursued by the media and respondents felt a certain response bias to be consistent with the prevailing norm. Also, the low sample size does not allow one to form any clear conclusions about the ethical leadership for the majority of Canadian business schools.

\section{Conclusion}

The continuing desire of leaders of the business world to be more ethical also resounds within the dean community of Canadian business schools. This marks a commitment by deans to increasing the profile and importance of ethics in management education and practice. The issue of the teaching of business ethics is connected to the larger issue of the relationship between school and society (Singh, 1989). While teaching ethics would not guarantee a reduction in the number of scandals, it would provide a framework for moral reasoning by business school graduates. Ultimately, the ethical decisions made by graduates in some way may be traced back to the curriculum offering of ethics courses and to a lesser degree to the ethical behaviours of their professors and deans while in school. This study clearly indicates that while deans in Canadian business schools generally frown upon unethical behaviour, there are some fuzzy instances that still lead to questionable decisions and inconsistencies across the group. 


\section{References}

Association to Advance Collegiate Schools of Business International (AACSBI) (2004) Ethics Education in Business Schools, St. Louis, Missouri.

Bart, C., Bontis, N. and Taggar, S. (2001) 'A model of mission statements and firm performance', Management Decision, Vol. 39, No. 1, pp.19-35.

Beauchamp, T.L. and Bowie, N.E. (1979) Ethical Theory and Business, Englewood Cliffs, NJ: Prentice Hall.

Bontis, N. (1999) 'Managing organizational knowledge by diagnosing intellectual capital: framing and advancing the state of the field', International Journal of Technology Management, Vol. 18, Nos. 5-8, pp.433-462.

Cordtz, D. (1994) 'Ethicsplosion', Financial World, 16 August, Vol. 94, p.38.

Fraedrich, J.P. (1990) 'Ethical awareness for the classroom: a framework', Journal of Education for Business, November-December, Vol. 66, p.88.

French, P.A. (1997) 'Value profiles of business students in the 1960s and in the 1990s: a comparison', Journal of Education for Business, January-February, Vol. 72, p.140.

Glasbeek, H.J. (1990) 'Business ethics in America: a view from the classroom', Journal of Behavioural Economics, Spring, Vol. 19, p.125.

Halfond, J. (1990) 'Should business schools be Sunday schools?', Business and Society Review, Vol. 72, pp.54-55.

MacMillan, J. (1995) 'The bottom line on ethics', US News and World Report, 20 March, p.61.

Manning, R.C. (1993) 'Business and academe: a comparison of perceptions on business ethics', Journal of Socio-Economics, Spring, Vol. 17, p.52.

Poff, D.C. and Waluchow, W.J. (1991) Business Ethics in Canada, Scarborough, ON: Prentice-Hall.

Rozensher, S.G. and Fergenson, P.E. (1994) 'Business faculty perspectives on ethics: a national survey', Business Horizons, July, Vol. 37, p.61.

Sherwin, D.S. (1992) 'Teaching business ethics', Journal of Education for Business, September-October, Vol. 68, p.5.

Siguaw, J.A., Rockness, J.W., Hunt, T.G. and Howe, L.V. (1998) 'Ethical values and leadership: a study of AACSB business schools deans', Academy of Management Proceedings - Social Issues in Management Division, San Diego, California.

Singh, J.B. (1989) 'The teaching of ethics in Canadian schools of business and administrative studies', Journal of Business Ethics, Vol. 8, No. 1, pp.51-56.

Stiles, C.A. (1998) 'Ethical decision-making: a challenge to college health practitioners', Journal of American College Health, July, Vol. 47, p.47.

Webber, R.A. (1990) 'Ethics gap', Chief Executive, May, Vol. 58, p.76. 


\section{Appendix}

1A. David Shaw, a wealthy alumnus and President and CEO of Shaw, Inc., who has previously donated substantial sums to the School of Engineering, offers Dean Mitchell a $\$ 1.5$ million contribution to the School of Engineering, if Dean Mitchell will remove a disciplinary action from the academic record of his daughter. His daughter is currently enrolled in the School and has been found guilty of a major honour code infraction. This is a first time offence and Dean Mitchell is also aware that upon graduation the daughter will work for Shaw Inc. Dean Mitchell also believes that not granting this favour may hinder continuous donations from the Shaw family in the future. Dean Mitchell accepts the offer and clears the record.

\section{A: Key points}

1 Dean clears disciplinary action from academic records

2 Dean accepts $\$ 1.5$ million contribution

Engineering School Deans generally participate in this type of activity:

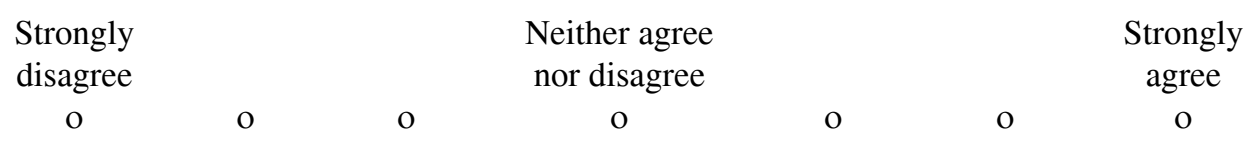

In a similar situation, I would participate:

\begin{tabular}{|c|c|c|c|c|c|}
\hline $\begin{array}{l}\text { Strongly } \\
\text { disagree }\end{array}$ & & & $\begin{array}{c}\text { Neither agree } \\
\text { nor disagree }\end{array}$ & & $\begin{array}{c}\text { Strongly } \\
\text { agree }\end{array}$ \\
\hline $\mathrm{O}$ & $\mathrm{O}$ & $\mathrm{O}$ & $\mathrm{O}$ & $\mathrm{O}$ & $\mathrm{O}$ \\
\hline
\end{tabular}

In my opinion, this action is:

Totally unethical

$\mathrm{O}$
Questionable

o
Totally ethical

$\mathrm{O}$

A Dean who participates in this type of activity should be:

Forced to resign

o
No action taken

$\mathrm{O}$
O
$\mathrm{O}$
O

1B. David Shaw, President and CEO of Shaw, Inc., has been a close personal friend of Dean Mitchell for the past 18 years. Mr. Shaw's daughter is currently enrolled in the School of Engineering and has recently been found guilty of a major honour code infraction. Dean Mitchell has been asked by his close friend to remove the disciplinary action from her academic records as a personal favour and as this is a first time offence. Dean Mitchell is aware that upon graduation, the daughter will be employed in the family-owned corporation and granting this favour will preserve his long-standing friendship. Dean Mitchell clears the record. 


\section{B: Key point}

1 Dean clears disciplinary action from academic records

2 Dean preserves life-long friendship

Engineering School Deans generally participate in this type of activity:

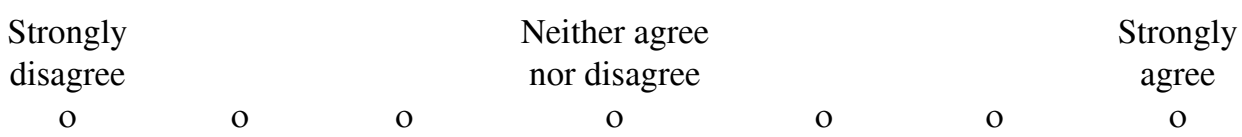

In a similar situation, I would participate:

$\begin{array}{ccccc}\begin{array}{c}\text { Strongly } \\ \text { disagree }\end{array} & \text { o } & \begin{array}{c}\text { Neither agree } \\ \text { nor disagree }\end{array} & \text { Strongly } \\ \text { agree }\end{array}$

In my opinion, this action is:

Totally unethical

o
Questionable
Totally ethical

A Dean who participates in this type of activity should be:

Forced to resign

$\mathrm{o}$
No action taken

$\mathrm{O}$
$\mathrm{O}$
$\mathrm{O}$
$\mathrm{O}$

2A. Dean Williams has an unexpected visit from Mr. Davison, his close personal friend of 15 years. Mr. Davison is very upset that his son's application to the engineering programme has been rejected and asks Dean Williams to reconsider the decision. Upon re-evaluation of the application, Dean Williams discovers that even though the son is close, he is clearly below the admissions cut-off points. Several other qualified applications for the engineering programme were also rejected, as the competition for admission was intense. Dean Williams reconsiders and decides to accept the application.

\section{A: Key point}

1 Dean accepts the application

2 Mr. Davison is a close friend

Engineering School Deans generally participate in this type of activity:

$\begin{array}{ccccc}\begin{array}{c}\text { Strongly } \\ \text { disagree }\end{array} & \text { Neither agree } & & \text { Strongly } \\ \text { o nor disagree } & \text { agree }\end{array}$


In a similar situation, I would participate:

$\begin{array}{lc}\text { Strongly } & \text { Neither agree } \\ \text { disagree } & \text { nor disagree }\end{array}$

o
$\mathrm{O}$
$\mathrm{O}$
Strongly

agree

$\mathrm{O}$

In my opinion, this action is:

Totally

unethical

o

\begin{abstract}
$\mathrm{O}$
\end{abstract}
Questionable

o
Totally

ethical

$\mathrm{O}$

A Dean who participates in this type of activity should be:

\section{Forced to resign}

$\mathrm{o}$
No action taken

o o o

o

2B. Dean Williams has an unexpected visit from Mr. Davison, a major on-going contributor to the School of Engineering with contributions over the past ten years totalling more than \$1 million. Mr. Davison is very upset that his son's application to the engineering programme has been rejected and asks Dean Williams to reconsider the decision. Upon re-evaluation of the application, Dean Williams discovers that even though the son is close, he is clearly below the admissions cut-off points. Several other qualified applications for the engineering programme were also rejected, as the competition for admission was intense. Dean Williams reconsiders and decides to accept the application.

\title{
B: Key point
}

1 Dean accepts the application

2 Mr. Davison is a major contributor

Engineering School Deans generally participate in this type of activity:

$\begin{array}{cccccc}\begin{array}{c}\text { Strongly } \\ \text { disagree }\end{array} & \text { Neither agree } & & \text { Strongly } \\ \text { nor disagree } & \text { agree }\end{array}$

In a similar situation, I would participate:

\section{Strongly}

disagree

$\mathrm{O}$

$\mathrm{O}$

Neither agree

Strongly nor disagree

$\mathrm{O}$

O agree

$\mathrm{O}$

In my opinion, this action is:

Totally unethical ethical 
A Dean who participates in this type of activity should be:

Forced to resign

No action taken

o

$\mathrm{O}$

$\mathrm{O}$

$\mathrm{O}$

$\mathrm{O}$

Rewarded

3A. Dean Ferry is discussing fund-raising ideas with George Anderson, alumnus of the School of Engineering on 10 February 1999. The Dean explains that the School of Engineering is desperately in need of discretionary funds for a new project to upgrade facilities. He has several ideas for fund-raising activities and presents them to Mr. Anderson for advice. Mr. Anderson in response, pulls out his chequebook and writes a cheque to the Engineering School for \$10,000, but backdates it to 30 December 1998, explaining that he needs the deduction for the 1998 tax year. Dean Ferry accepts the cheque.

\section{A: Key point}

1 Dean accepts the backdated cheque for $\$ 10,000$

Engineering School Deans generally participate in this type of activity:

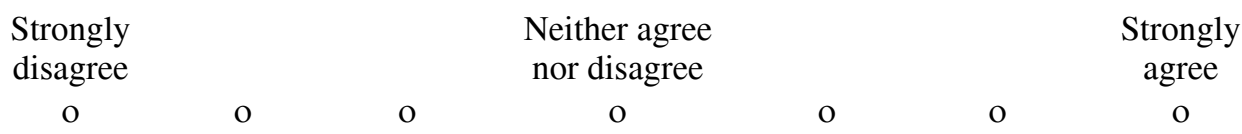

In a similar situation, I would participate:

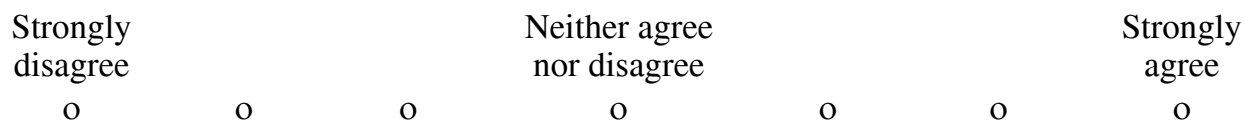

In my opinion, this action is:

Totally unethical$$
\text { o }
$$

Questionable

$$
\text { o }
$$

Totally ethical

o

A Dean who participates in this type of activity should be: Forced to
resign

o

o
No action taken

o
Rewarded

o

3B. Dean Ferry is discussing fund-raising ideas with George Anderson, alumnus of the School of Engineering on 10 February 1999. The Dean explains that the School of Engineering is desperately in need of discretionary funds for a new project to upgrade facilities. He has several ideas for fund-raising activities and presents them to Mr. Anderson for advice. Mr. Anderson in response, pulls out his chequebook and writes a cheque to the Engineering School for \$200,000, but back dates it to 30 December 1998 explaining that he need the deduction for the 1998 tax year. Dean Ferry accepts the cheque. 


\section{B: Key point}

1 Dean accepts backdated cheque for $\$ 200,000$

Engineering School Deans generally participate in this type of activity:

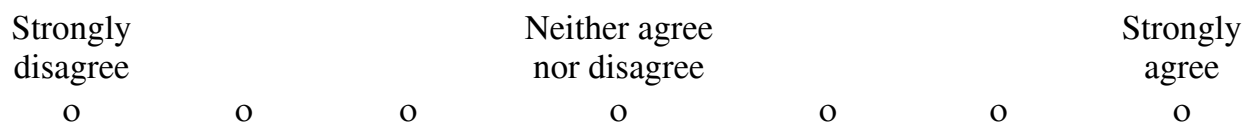

In a similar situation, I would participate:

Strongly disagree

o
O

Neither agree nor disagree
Strongly agree

o

In my opinion, this action is:

Totally unethical

o
Questionable

o
Totally ethical

$\mathrm{o}$

A Dean who participates in this type of activity should be:

Forced to resign

o
No action taken

o
$\mathrm{O}$
$\mathrm{O}$
$\mathrm{O}$

4A. As the Dean of the School of Engineering for the past 12 years, Dean Allen has developed a close professional relationship with Mrs. Leonis, a wealthy, elderly widow and an avid supporter of education. Her generous contributions to the School of Engineering in the past have made her one of the top contributors of all time. She has also promised to continue to support the School through a bequest in her will. Upon her death, however, Dean Allen learns that a $\$ 90,000$ bequest from her estate is willed to him personally. Dean Allen decides to keep the money personally as opposed to donating it to the School of Engineering funds.

\section{A: Key point}

1 Dean keeps $\$ 90,000$ bequest personally

Engineering School Deans generally participate in this type of activity:

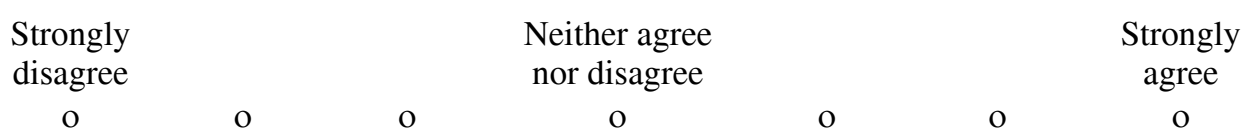

In a similar situation, I would participate:

Strongly
disagree

o
Neither agree nor disagree
Strongly
agree

$\mathrm{O}$ 
In my opinion, this action is:

Totally unethical

o o
Questionable

$\mathrm{o}$
Totally

ethical

$\mathrm{O}$

A Dean who participates in this type of activity should be:

Forced to resign

No action taken

Rewarded

o

o

O

o

o

O

4B. As the Dean of the School of Engineering for the past 12 years, Dean Allen has developed a close professional relationship with Mrs. Leonis, a wealthy, elderly widow and an avid supporter of education. Her generous contributions to the School of Engineering in the past have made her one of the top contributors of all time. She has also promised to continue to support the School through a bequest in her will. Upon her death, however, Dean Allen learns that a $\$ 9,000$ bequest from her estate is willed to him personally. Dean Allen decides to keep the money personally as opposed to donating it to the School of Engineering funds.

\section{B: Key point}

1 Dean keeps $\$ 9,000$ bequest personally

Engineering School Deans generally participate in this type of activity:

Strongly

disagree

o

$\mathrm{O}$

\section{Neither agree \\ nor disagree}

Strongly agree

o

In a similar situation, I would participate:

Strongly

disagree
Neither agree nor disagree
Strongly agree

o

In my opinion, this action is:

Totally unethical

$\mathrm{O}$
Questionable

$\mathrm{O}$
Totally ethical

A Dean who participates in this type of activity should be:

Forced to resign

No action taken

Rewarded

$\mathrm{O}$

$\mathrm{O}$

$\mathrm{O}$ 
$5 A$. Dean Preston is personally requesting donations from several of the engineering school alumni. Philip Taylor, a successful executive of a large contracting firm pledges to support the annual fund with a $\$ 200,000$ donation in return for a list of faculty and administrators coming to and leaving the university each year. Mr. Taylor also offers subsequent payments of $\$ 5,000$ for the next five years. Dean Preston accepts the offer.

\section{A: Key points}

1 Dean accepts $\$ 200,000$ donation with subsequent payments of $\$ 5,000$

2 Dean hands over list of faculty and administrators

Engineering School Deans generally participate in this type of activity:

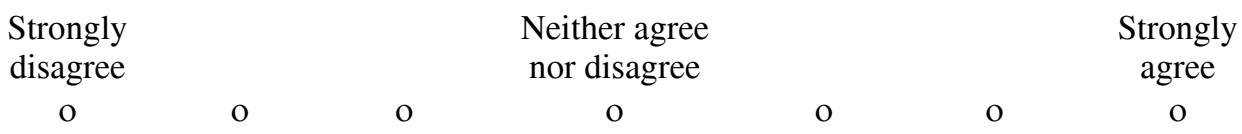

In a similar situation, I would participate:

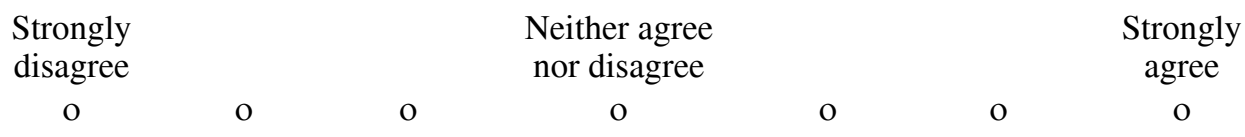

In my opinion, this action is:

Totally unethical

$$
\text { o }
$$

\section{Questionable}

o
Totally ethical

o

A Dean who participates in this type of activity should be:

Forced to resign

o
No action taken

o
Rewarded o

$5 B$. Dean Preston is personally requesting donations from several of the engineering school alumni. Philip Taylor, a successful executive of a large contracting firm pledges to support the annual fund with a $\$ 20,000$ donation in return for a list of faculty and administrators coming to and leaving the university each year. Mr. Taylor also offers subsequent payments of $\$ 1,000$ for the next five years. Dean Preston accepts the offer.

\section{B: Key points}

1 Dean accepts $\$ 20,000$ donation and subsequent payments of $\$ 1,000$

2 Dean hands over list of faculty and administration 
Engineering School Deans generally participate in this type of activity:

Strongly disagree

o
Neither agree nor disagree

$\mathrm{O}$

Strongly

agree

o

In a similar situation, I would participate:
Strongly

disagree

$\mathrm{O}$
$\mathrm{O}$

Neither agree nor disagree

$\mathrm{o}$

o

$\mathrm{O}$

Strongly agree

o

In my opinion, this action is:

Totally

unethical

Questionable

$\mathrm{O}$

o

$\mathrm{O}$

o

o

Totally ethical o

A Dean who participates in this type of activity should be:

Forced to resign

No action taken

o

o

o

$\mathrm{O}$

o

O

Rewarded

$\mathrm{o}$ 